\title{
Media for Enhanced Phosphorus Removal from Secondary Wastewater Effluent
}

\author{
Margaret Greenway, Griffith School of Engineering, Nathan Campus, Qld 4111 \\ m.greenway@griffith.edu.au
}

\begin{abstract}
Constructed subsurface flow wetlands have the potential for high phosphorus removal through chemical adsorption onto the media. Over the past decade researchers at Griffith University, Australia have been using 240L mesocosms to investigate the long term sustainability and performance efficiency of using different soil media and plant species to maximise nutrient removal from secondary wastewater effluent. The performance efficiency of fifteen different media mixes including amendments for enhanced phosphorus adsorption, and ten different plant species have been investigated.

Total Phosphorus removal was highest (94-99\%) in sand media amended with Water Treatment Residuals (WTR), followed by 'brickies loam' (92\%), then sand amended with Red Mud or Krasnozems (86-89\%) and lowest in gravel (44\%). Phosphorus removal using sand with WTR had the greatest efficiency when treating influent with $\mathrm{P}$ concentrations ranging from $0.5-8 \mathrm{mg} / \mathrm{L}$ (90-99\%). The addition of biochar to sand did not enhance $\mathrm{P}$ removal during a 2 year trial.

Leaching and export of $\mathrm{P}$ occurred from the media either after heavy rain or loading with stormwater having low P concentrations $(<0.06 \mathrm{mg} / \mathrm{L})$. However, following such 'flushing events' $\mathrm{P}$ sorption and hence $\mathrm{P}$ removal efficiency were enhanced.

Mature plant assemblages could uptake up to $16 \mathrm{gP} / \mathrm{m} 2 /$ year. Of the herbaceous plants the perennial grasses Pennisetum alopecuroides and Vetiver -Chrysopogon zizanioides, and the sedge Carex appressa had the highest biomass. The woody species Callistemon pachyphyllus and Melaleuca quinquenervia had the highest carbon sequestration $(1000 \mathrm{~g} \mathrm{C} / \mathrm{m} 2 / \mathrm{y})$. Thus various sandy loam media can be used to enhance long term effective phosphorus removal, and plants can be used for carbon credits.

Key Words: Constructed wetlands, plants, phosphorus removal, sewage effluent, media.
\end{abstract}

\section{INTRODUCTION:}

Nutrient removal from municipal wastewater and urban stormwater is essential prior to release into natural water bodies to prevent eutrophication and safeguard downstream ecosystem health. In the wastewater industry Membrane Bioreactors (MBR) and Biological Nutrient Removal (BNR) are advanced technological processes to improve nutrient removal; however these technologies come at considerable installation, operational and life-cycle costs and have high energy usage (high carbon emissions). Alum dosing is used to achieve low phosphorus discharge concentrations but this is costly and introduces harmful chemicals into the environment.

Constructed wetlands are efficient ecotechnologies for wastewater treatment with the advantage of low cost, simple operation and low maintenance (Kadlec and Wallace, 2008). Unfortunately constructed wetlands are not being used widely enough for the treatment of sewage effluent, and yet these vegetated filter systems have proven to be highly effective in the removal of total suspended solids, biological oxygen demand, pathogens and nitrogen(Abou-Elela et al., 2013; de Rozari et al., 2015) however phosphorus removal is still a challenge (Ayaz et al., 2012; Vymazal, 2007). 
Whilst most wetland processes for contaminant removal are dependent on plants and microorganisms (Greenway, 2004), the removal of phosphorus relies on the chemical processes of sorption and /or precipitation. Hence it is the soil media that most strongly influences $\mathrm{P}$ removal capacity. Freewater surface flow wetlands thus have a more limited capacity for P removal (Greenway, 2005) than subsurface flow wetlands (horizontal flow and vertical flow) (Kadlec and Wallace, 2008). Arias et al., 2001; Arias \& Brix, 2001 and Westholm 2006 recognised the importance of trialing different media to enhance phosphorus removal. In his review Vymazal (2007) reported 60\% TP removal but since then researchers have used a wide range of both natural and manmade media materials to enhance long term phosphorus removal and retention (Vohla et al.,2011; Ayaz et al., 2012, Ayaz et al.,2012; Sani et al. ,2013; Martín et al. ,2013)

In 2003 researchers at Griffith University commenced a series of vertical flow wetland mesocosms experiments focused on investigating media and plants for long term nutrient retention capabilities. This paper summarises the findings of 12 years research (2003 to 2015) into the effectiveness of 15 different media types for phosphorus adsorption from sewage effluent.

\section{METHODS}

\section{Experimental set up: media and plants}

To investigate the performance of different soil media and plant species we used 240L mesocosms (wheelie bins) (Fig. 1) with a surface area $0.25 \mathrm{~m}^{2}$. Media depths ranged from $58-$ $62 \mathrm{~cm}$ and were underlain with a $15 \mathrm{~cm}$ gravel drainage layer. All experiments were conducted at the Loganholme Water Pollution Control Centre, near Brisbane, Australia.

In Experiment 1 (2003) thirty mesocosms were constructed using 3mm gravel, sand with 4\% silt/clay and loamy sand (89\% sand, 8\% silt, 3\% clay) referred to as "loam" (Henderson et al, 2007, Henderson, 2008). The vegetated 'gravel' mesocosms contained 20cm sand on top of $60 \mathrm{~cm}$ gravel. There were 10 mesocosms for each media (5 with vegetation, 5 unvegetated). Each vegetated mesocosm contained 5 species: 3 herbaceous and 2 shrubs. The mesocosms set up was modified in 2007 with the addition of 150L collection chambers supplied by Vinidex (Lucas \& Greenway, 2008; Greenway \& Lucas, 2009)

In Experiment 2 (2007) a further 27 mesocosms were constructed using sandy media amended with varying proportions of Red Mud, Krasnozem soil and Water Treatment Residuals (Table 1 ); coir peat ( $12 \%$ by volume) was added to assist in moisture retention; there were 3 replicates for each media type (Lucas \& Greenway, 2011a; Lucas,2013). The Red Mud, a by-product of refining bauxite to aluminium was supplied by Alcan; the Krasnozem soils, derived from weathered basalt comprising amorphous aluminium complexes, were obtained locally, and the Water Treatment Residuals, amorphous alum sludge a waste product of drinking water treatment, were obtained from Stradboke Island Water Treatment Plant. Each mesocosm contained 4 species: 3 herbaceous and 1 shrub. The mesocosms were designed with elevated outlets (Fig 1). 
Table 1. Composition of different media by \% weight used in Experiments 1, 2 3and $4 . \quad$ (S Sand; RM- Red Mud; K - Krasnozem; WTR - Water Treatment Residuals, BC-Biochar; P - total phosphorus content of media $\mathrm{mg} / \mathrm{Kg}$, OM - organic matter.) Note $12 \%$ by volume of coir peat was added in Expt 2, 3and 4.

\begin{tabular}{|l|l|l|l|l|l|l|l|l|l|l|l|}
\hline Media Mix & symbol & Expt & $\begin{array}{l}\text { Sand } \\
\%\end{array}$ & $\begin{array}{l}\text { Loam } \\
\%\end{array}$ & $\begin{array}{l}\text { RM } \\
\%\end{array}$ & $\begin{array}{l}\text { K } \\
\%\end{array}$ & $\begin{array}{l}\text { WTR } \\
\%\end{array}$ & $\begin{array}{l}\text { Top } \\
\text { Soil }\end{array}$ & $\begin{array}{l}\text { BC } \\
\%\end{array}$ & $\begin{array}{l}\text { Pmg } \\
/ \text { Kg }\end{array}$ & $\begin{array}{l}\text { OM } \\
\%\end{array}$ \\
\hline Gravel+S & GV & 1 & 33 & & & & & & & & \\
\hline Sand & S/SV & 1 & 100 & & & & & & & 25 & 0.2 \\
\hline Loam & L/LV & 1 & & 100 & & & & & & 130 & 0.6 \\
\hline S+ RM & RM06 & 2 & 75 & & 5 & & & 20 & & 32 & 1.8 \\
\hline S+ RM & RM10 & 2 & 71 & & 9 & & & 20 & & 32 & 2.5 \\
\hline S+ K & K20 & 2 & 86 & & & 14 & & & & 70 & 3.5 \\
\hline S+ K & K30(10-40) & 2 & 70 & & & 30 & & & & 80 & 3.7 \\
\hline S+ K & K40 & 2 & 70 & & & 30 & & & & 80 & 2.5 \\
\hline S+WRT & WTR30 & 2 & 80 & & & & 20 & & & 150 & 4.2 \\
\hline S +WTR+ K & WTR+K & 2 & 71 & & & 20 & 9 & & & 100 & 4.1 \\
\hline S+WTR & WTRMC & 3 & 80 & & & & 20 & & & 555 & 4.6 \\
\hline Sand & S100 & 4 & 100 & & & & & & & 60 & 0.4 \\
\hline S+BC & BC5 & 4 & 95 & & & & & & 5 & 50 & 1.3 \\
\hline S+BC & BC10 & 4 & 90 & & & & & & 10 & 55 & 2.2 \\
\hline S+BC & BC20 & 4 & 80 & & & & & & 20 & 58 & 4.5 \\
\hline
\end{tabular}

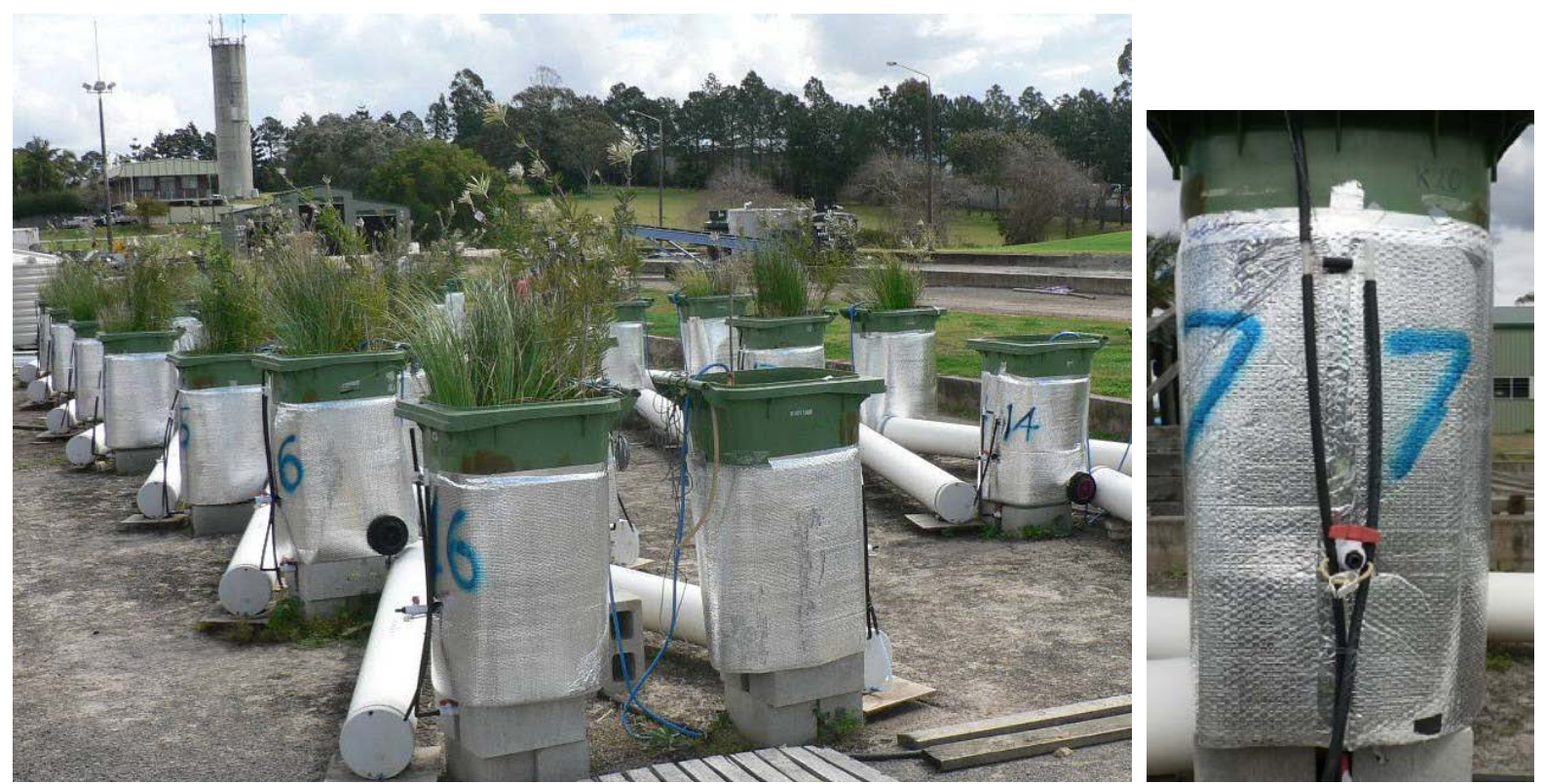

Figure 1. Experiment 2 - Mesocosms with elevated outlets and collection chambers at Loganholme Water Pollution Control Centre. Source: Lucas \& Greenway (2011b).

In Experiment 3 (2009) another 12 mesocosms with elevated outlets were constructed using 80\% sand and 20\% Water Treatment Residuals (obtained from the Mt Crosby Water Treatment Plant, Brisbane). Each mesocosm had 5 species: 3 herbaceous and 2 shrubs. 
In Experiment 4 (2013) another 21 mesocosms were constructed using sand and varying proportions of biochar derived from Eucalyptus wood (de Rozari et al., 2015). Only 4 media mixes are presented in this paper (Table 1). Each mesocosm had a grass and a shrub.

\section{Sewage Effluent Loading Regimes:}

In Experiments1, 2, 3 the mesocosms were intermittently loaded at either weekly, 2 weekly or monthly intervals. Inflow volumes varied between 90 to $135 \mathrm{~L}$ and the entire outflow volume was collected in 150L cylindrical PVC chambers. Composite samples were collected within 12 hours.

In Experiment 4 the mesocosms received a continuous flow of secondary clarified effluent for the first 8 months at a 4 day HRT. For the next 9 months they were intermittently loaded at 3 day intervals with septage. The outflows were collected and stored in the PVC chambers and composite samples taken every 2 weeks (de Rozari et al., 2016).

In Experiment1 the mesocosms were initially loaded with stormwater (July 2003-December 2005) (Henderson et al. 2007; Henderson, 2008) and received a total load $\left(\mathrm{g} / \mathrm{m}^{2}\right.$ ) of $4.58 \mathrm{~g} \mathrm{TP}$, $3.72 \mathrm{~g} \mathrm{PO}_{4}$, From August 2006 the mesocosms were irrigated with recycled sewage effluent (average composition: $4.8 \mathrm{mg} \mathrm{TP}, 3.94 \mathrm{mg} \mathrm{PO}_{4} \mathrm{~L}^{-1}$ ). Over the next 12 months the mesocosms were irrigated weekly and received a total load $\left(\mathrm{g} / \mathrm{m}^{2}\right)$ of $109.6 \mathrm{~g}$ TP, 83.5 g PO 4 , (Lucas \& Greenway, 2008; Greenway \&Lucas, 2009).

In Experiment 2(2007- 2010) the mesocosms continued to be irrigated with recycled effluent (average composition: $4.8 \mathrm{mg} \mathrm{TP}, 3.94 \mathrm{mg} \mathrm{PO}_{4}, \mathrm{~L}^{-1}$ ), with occasional 'stormwater rinsing' (average composition $0.78 \mathrm{mg} \mathrm{TP}, 0.57 \mathrm{mg} \mathrm{PO}_{4}, \mathrm{~L}^{-1}$ ) (Lucas \& Greenway, 2011a,c; Lucas, 2013). Over 3 years the mesocosms received a total load $\left(\mathrm{g} / \mathrm{m}^{2}\right)$ of $260 \mathrm{~g} \mathrm{TP}, 213 \mathrm{~g} \mathrm{PO}_{4}$,

Experiment 3(2009-2013) was designed to investigate the effects of different phosphorus inflow concentrations on removal efficiency, in particular any leaching from the WTR media mix. Eight mesocosms were irrigated with synthetic stormwater (average composition $0.46 \mathrm{mg} \mathrm{TP}, 0.43 \mathrm{mg} \mathrm{PO}_{4}$,) and four mesocosms were irrigated with recycled effluent (average composition: 3.63mg TP, 3.35mg $\mathrm{PO}_{4} \mathrm{~L}^{-1}$ ). Over 4 years the stormwater irrigated mesocosms received a total load $\left(\mathrm{g} / \mathrm{m}^{2}\right) 8 \mathrm{~g} \mathrm{TP}$, while the effluent irrigated mesocosms received $102 \mathrm{gTP}$.

Experiment 4 (2013-2015) was designed to investigate phosphorus removal from sewage effluent with higher $\mathrm{P}$ concentrations. The 2 sources were secondary clarified effluent (average composition: 6.45mg TP, 5.10mg $\mathrm{PO}_{4} \mathrm{~L}^{-1}$ ) and septage ((average composition: 24.45mg TP, 20.10mg $\mathrm{PO}_{4} \mathrm{~L}^{-1}$ ) (de Rozari et al. 2016). Total load was not determined.

\section{Plant biomass and nutrient accumulation:}

Sub samples of plant components were regularly analysed for N, P and Carbon tissue content. Shoots of grass and sedge species were cropped every 6 months to determine harvestable shoot biomass and to encourage regrowth. Total biomass harvesting of both above and below ground biomass was conducted after 4.5 years in Experiment 1, after 2 and 3 years in Experiment 2 , yearly in Experiment 3 and after 17 and 21 months in Experiment 4.

\section{RESULTS/DISCUSSION}

Nutrient Retention: Tables 2, 3, 4 summarise the results of these experiments. For comparison, mass retention has been normalized to $\mathrm{g} / \mathrm{m}^{2} / \mathrm{y}$ and is based on the annual mean over the duration of the treatments. 


\section{Experiment 1}

Treatment performance with the recycled effluent (between years 3 \& 4) phosphorus retention was higher in the vegetated mesocosms, with vegetated loam having the highest removal efficiency (92\% retention TP; $100 \mathrm{~g}-\mathrm{m}^{-2}-\mathrm{y}^{-1}$ ). The higher performance efficiency of the vegetated media is also reflected in Fig 2 . Of the barren media, gravel had the lowest $\mathrm{P}$ removal efficiency (15\%) indicating it had reached $\mathrm{P}$ sorption capacity (also refer to Figure 2).

Table 2. Comparison of annual mass retention $\left(g-\mathrm{m}^{-2}-\mathrm{y}^{-1}\right) \& \% P$ removal efficiency for different media in Experiment 1in Year 4.Source: Lucas \& Greenway, 2008, 2011a, c; Lucas 2013

\begin{tabular}{|l|c|c|c|c|}
\hline Experiment 1 & \multicolumn{2}{|c|}{ PO4-P } & \multicolumn{2}{c|}{ TP } \\
\hline & $\mathrm{g} / \mathrm{m} 2 / \mathrm{y}$ Retention & \% Removal & $\mathrm{g} / \mathrm{m} 2 / \mathrm{y}$ Retention & \% Removal \\
\hline Gravel & $\mathbf{1 6}$ & 17 & $\mathbf{1 6}$ & 15 \\
\hline GVeg & $\mathbf{3 5}$ & 39 & $\mathbf{4 8}$ & 44 \\
\hline Sand & $\mathbf{3 0}$ & 33 & $\mathbf{4 2}$ & 38 \\
\hline SVeg & $\mathbf{5 6}$ & 62 & $\mathbf{7 3}$ & 67 \\
\hline Loam & $\mathbf{4 6}$ & 50 & $\mathbf{6 2}$ & 56 \\
\hline LVeg & $\mathbf{8 1}$ & 89 & $\mathbf{1 0 0}$ & 92 \\
\hline
\end{tabular}

Henderson (2008) and Henderson et al (2007b) investigated the sorption and desorption behaviour of nutrients in the loam media The media in the mesocosms which had received a total load of between $2.8 \mathrm{~m}^{-2}$ and $3.31 \mathrm{~g} \mathrm{~m}^{-2} \mathrm{PO}_{4}-\mathrm{P}$ no longer had the capacity to sorb more $\mathrm{PO}_{4}-\mathrm{P}$ at stormwater concentrations $\left(0.55 \mathrm{mg} . \mathrm{L}^{-1} \mathrm{PO}_{4}\right)$. The sorption isotherms indicated that for further sorption to occur the equilibrating solution would need to have a $\mathrm{PO}_{4}-\mathrm{P}$ concentration greater than $1.5 \mathrm{mg} \mathrm{L}^{-1}$. This was supported by the subsequent research of Lucas \& Greenway (2007) presented in Fig.2 when the same mesocosms were loaded with recycled effluent (year 3-4) with $\mathrm{PO}_{4}-\mathrm{P}$ concentrations between 3.3-6 mg L ${ }^{-1}$. Fig. 2 which compares inflow and outflow concentrations of TP, showed less phosphorus removal over time as the cumulative load increased. After the application of $40 \mathrm{gm}^{2}$ the mesocosms were leached with tap water and then dosed with stormwater which resulted in some desorption.

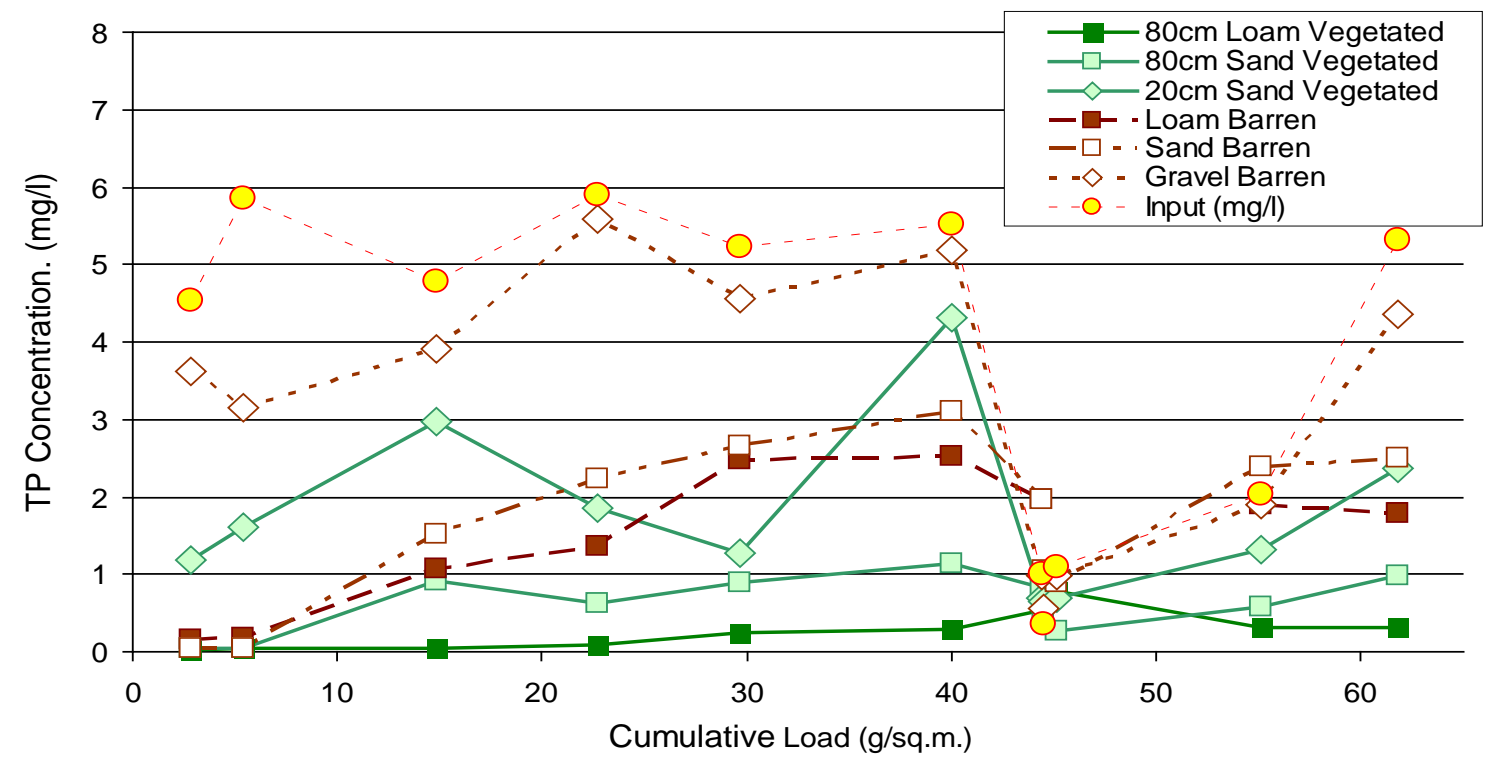

Figure 2: Input and output concentrations $\mathrm{mg} \mathrm{L}^{-1}$ phosphorous in vegetated and barren media as a function of cumulative load. 
Even though the original loam media contained $130 \mathrm{mg} \cdot \mathrm{kg}^{-1}$ phosphorus it still had the greatest phosphorus adsorption capacity. As shown in Fig 2, even after receiving a total load of $65 \mathrm{~g} \mathrm{Pm}^{-2}$ both the barren loam and vegetated loam mesocosms were capable of reducing phosphorus input concentrations from $5.3 \mathrm{mg} / \mathrm{l}$ to 1.8 and $0.2 \mathrm{mg} / \mathrm{l}$ respectively .

\section{Experiment 2}

Over the first 2 years, all media had high performance efficiencies for phosphorus ranging from 86-99\% with annual mean mass retentions ranging from $70-80 \mathrm{~g} \mathrm{PO}_{4} \mathrm{~m}^{-2}-\mathrm{y}^{-1}$ and $73-90 \mathrm{~g}$ $\mathrm{P} \mathrm{m}^{-2}-\mathrm{y}^{-1}$. The media amended with water treatment residuals (WTR+K and WTR30) had the highest P removal (98/99\%), followed by the media amended with Red Mud (RM10). Even after 3 years with a total load $\left(\mathrm{g} / \mathrm{m}^{2}\right)$ of $213 \mathrm{~g} \mathrm{PO}_{4}$ and $260 \mathrm{~g} \mathrm{TP}$, the RM10, WTR+K and WTR30 media showed no evidence of reduction in $\mathrm{P}$ retention, confirming high $\mathrm{P}$ sorption capacity. In Experiment 2 there was only one non-vegetated treatment (K20), P removal efficiency in this non vegetated media was $77 \%$ compared to $90 \%$ in the vegetated K20.

Table 3. Comparison of annual mass retention $\left(g-\mathrm{m}^{-2}-\mathrm{y}^{-1}\right) \& \%$ removal efficiency for different media in Experiment 2. Source: Lucas \& Greenway, 2011a, c; Lucas 2013;

\begin{tabular}{|l|c|c|c|c|}
\hline Experiment 2 & \multicolumn{2}{|c|}{ PO4-P } & \multicolumn{2}{c|}{ TP } \\
\hline Media & $\mathrm{g} / \mathrm{m} 2 / \mathrm{y}$ Retention & \% Removal & $\mathrm{g} / \mathrm{m} 2 / \mathrm{y}$ Retention & \% Removal \\
\hline RM06 & $\mathbf{7 0}$ & 92 & $\mathbf{8 6}$ & 88 \\
\hline RM10 & $\mathbf{6 9}$ & 96 & $\mathbf{8 3}$ & 93 \\
\hline K20 & $\mathbf{6 7}$ & 90 & $\mathbf{7 8}$ & 87 \\
\hline K30 & $\mathbf{6 8}$ & 89 & $\mathbf{7 8}$ & 86 \\
\hline K40 & $\mathbf{5 8}$ & 83 & $\mathbf{6 9}$ & 83 \\
\hline WTR+K & $\mathbf{6 1}$ & 94 & $\mathbf{8 2}$ & 93 \\
\hline WTR 30 & $\mathbf{6 4}$ & 99 & $\mathbf{8 6}$ & 98 \\
\hline
\end{tabular}
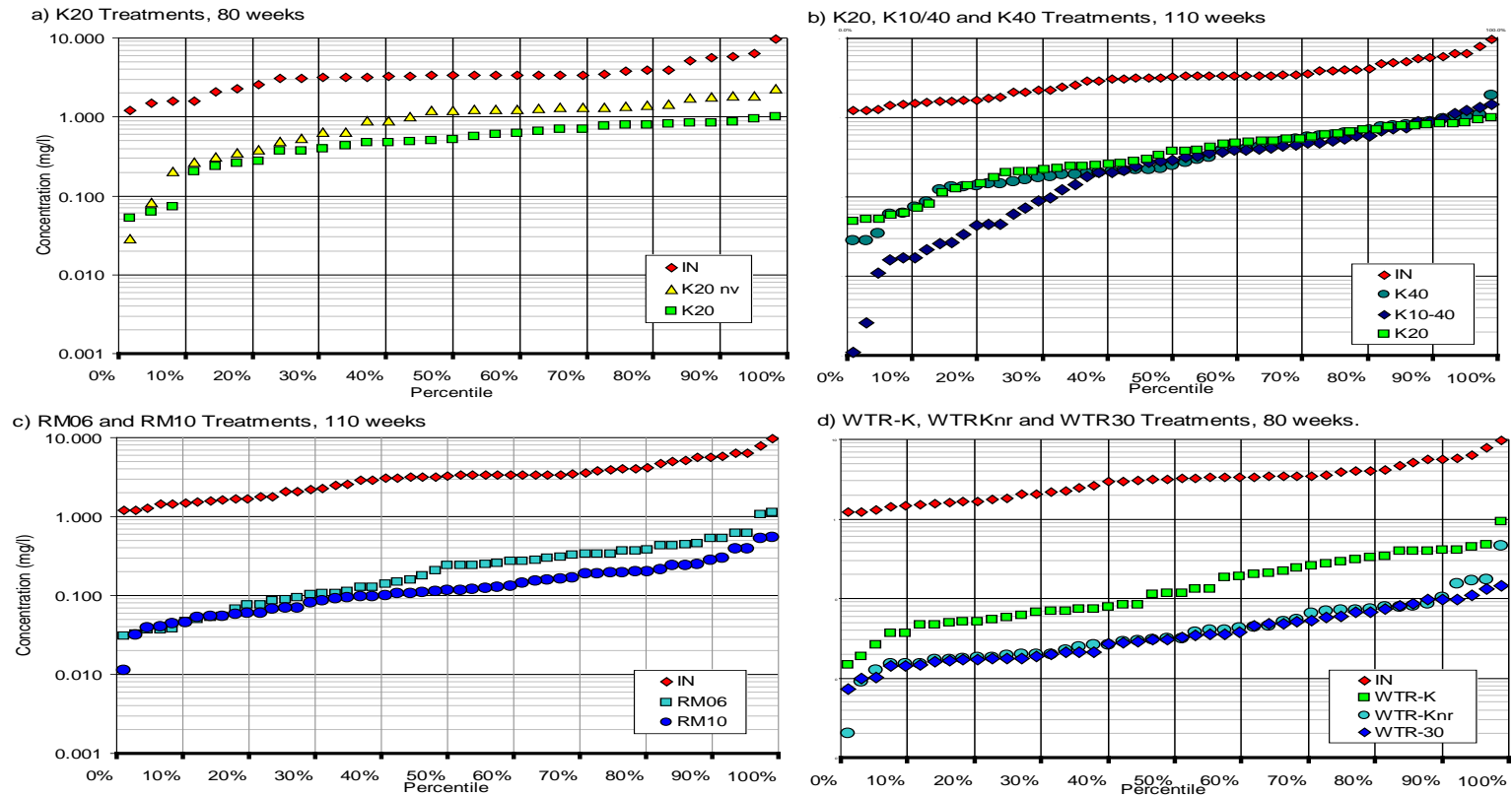

Figure 3: Experiment 2- Ortho-phosphate inflow and outflow concentrations during effluent loading regimes (mg- $\left.\mathbf{L}^{-1}\right)$. a) K 20nv and K20 treatments, 80 weeks. b) K20, K10/40 and K40 treatments, 110 weeks. c) RM06 and RM10 treatments, 110 weeks. d) WTR-K, WTR-Knr, and WTR30 treatments, 80 weeks. $\mathrm{nv}$ = non-vegetated; $\mathrm{nr}=$ non-restricted outlet. Source: Lucas and Greenway 2011a, Lucas, 2013) 
Fig 3 presents the cumulative frequency distribution of inflow and outflow concentrations for PO4 over 80 weeks and 110 weeks. Inflow concentrations ranged from 1-10mg/l. For the K20 treatments outflow concentrations from the vegetated mesocosms (K20) were lower than the barren mesocosms (K20nv). At inflow concentrations greater than $1.2 \mathrm{mg} / \mathrm{l}$, the K20, K30 (10-40) and K40 treatments, the outflow concentrations were statistically identical, but at lower inflow concentrations the K30(10-40) treatment achieved the lowest outflow concentrations. The RM treatments were generally more effective than the $\mathrm{K}$ treatments, whereas the WTR treatments were the most effective with $50 \%$ of outflow concentrations below 1mg/l.

\section{Experiment 3}

The mesocosms treated with recycled effluent maintained a performance efficiency of 99\% $\mathrm{P}$ removal over the 4 years (Table4), comparable to the performance of the WTR treatments in Experiment2. Expt 3 received a lower mass load than Expt 2, with annual loads gradually decreasing over time (Table 4), however even after a total load of $186 \mathrm{~g} / \mathrm{m} 2 \mathrm{TP}$ the media continued to remove almost all the phosphorus.

Table 4. Comparison of annual mass retention $\left(g-\mathrm{m}^{-2}-\mathrm{y}^{-1}\right) \& \%$ removal efficiency over 4 years in Expt 3 using sand media (80\%) with Mt Crosby WTR (20\%).Source: Greenway unpublished.

\begin{tabular}{|c|c|c|c|c|}
\hline Experiment 3 & \multicolumn{2}{|c|}{ PO4-P } & \multicolumn{2}{c|}{ TP } \\
\hline Year & $\mathrm{g} / \mathrm{m} 2 / \mathrm{y}$ Retention & \% Removal & $\mathrm{g} / \mathrm{m} 2 / \mathrm{y}$ Retention & \% Removal \\
\hline 1 & $\mathbf{5 7}$ & 99 & $\mathbf{5 9}$ & 99 \\
\hline 2 & $\mathbf{5 1}$ & 99 & $\mathbf{5 3}$ & 99 \\
\hline 3 & $\mathbf{4 1}$ & 99 & $\mathbf{4 3}$ & 98 \\
\hline 4 & $\mathbf{2 9}$ & 99 & $\mathbf{3 1}$ & 97 \\
\hline TOTAL-4years & $\mathbf{1 7 8 g / m 2}$ & & $\mathbf{1 8 6 g / m 2}$ & \\
\hline
\end{tabular}

\section{Experiment 4}

During the first 8 months loading with secondary clarified effluent the sand only S100 mesocosms performed better than the mesocosm with added biochar (BC)(Fig.4). Outflow concentrations in S100 were consistently below $2 \mathrm{mg} / \mathrm{L}$ and removal efficiency in S100 ranged from 71-90\%forTP and 73-92\% for PO4-P (de Rozari et al. 2016).

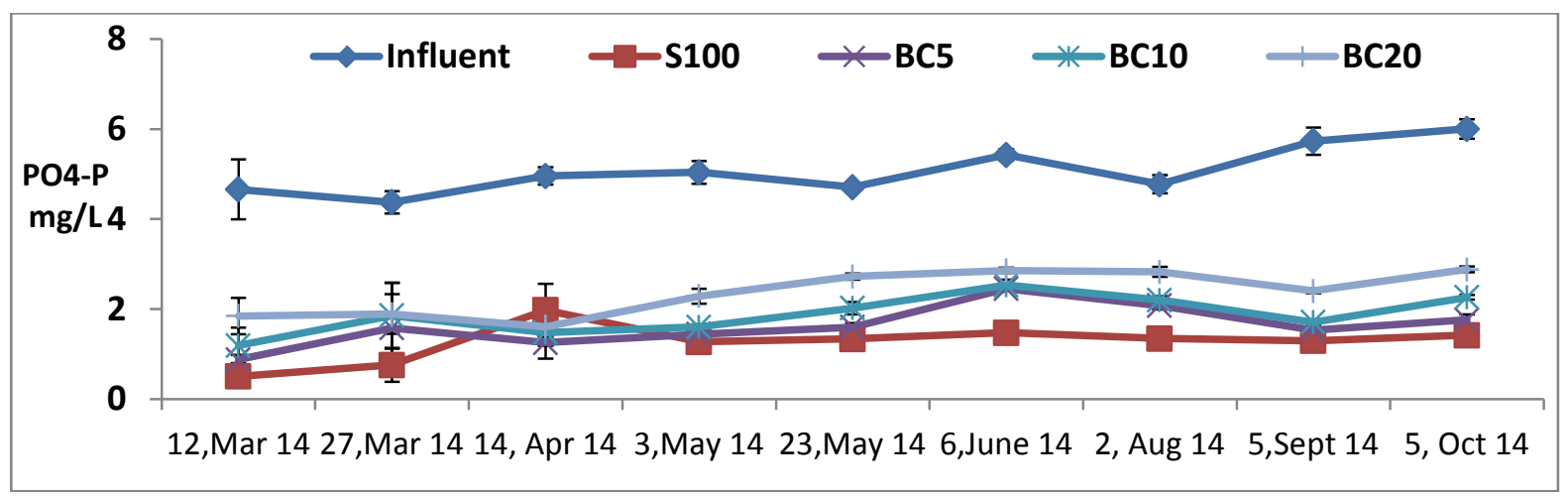

Figure 4: Experiment 4- Ortho-phosphate $P$ influent and outflow concentrations during clarified secondary effluent loading regime (mg-L $\left.{ }^{-1}\right)$. de Rozari et al. 2016 
During the first 4 months of loading with septage, the sand only S100 mesocosms continued to perform better than the mesocosms with added biochar (BC)(Fig.5).However between 1921February 2015 almost 200mm heavy rainfall (HR) occurred causing leaching of phosphorus(Fig.5). Subsequently all mesocosm treatments showed higher phosphorus retention (Fig.5) and performance removal efficiency (Fig 6). This phenomenon is similar to the "reset mechanism" described by Lucas and Greenway (2011). The BC5 and BC10 mesocosms were destroyed in March 2015 for plant biomass. P removal in the remaining S100 and BC20 mesocosms over the next 5 months showed no significant difference in performance between the 2 treatments. TP and PO4-P removal ranged from 63-71\%.and 6674\% respectively ((de Rozari et al. 2016).
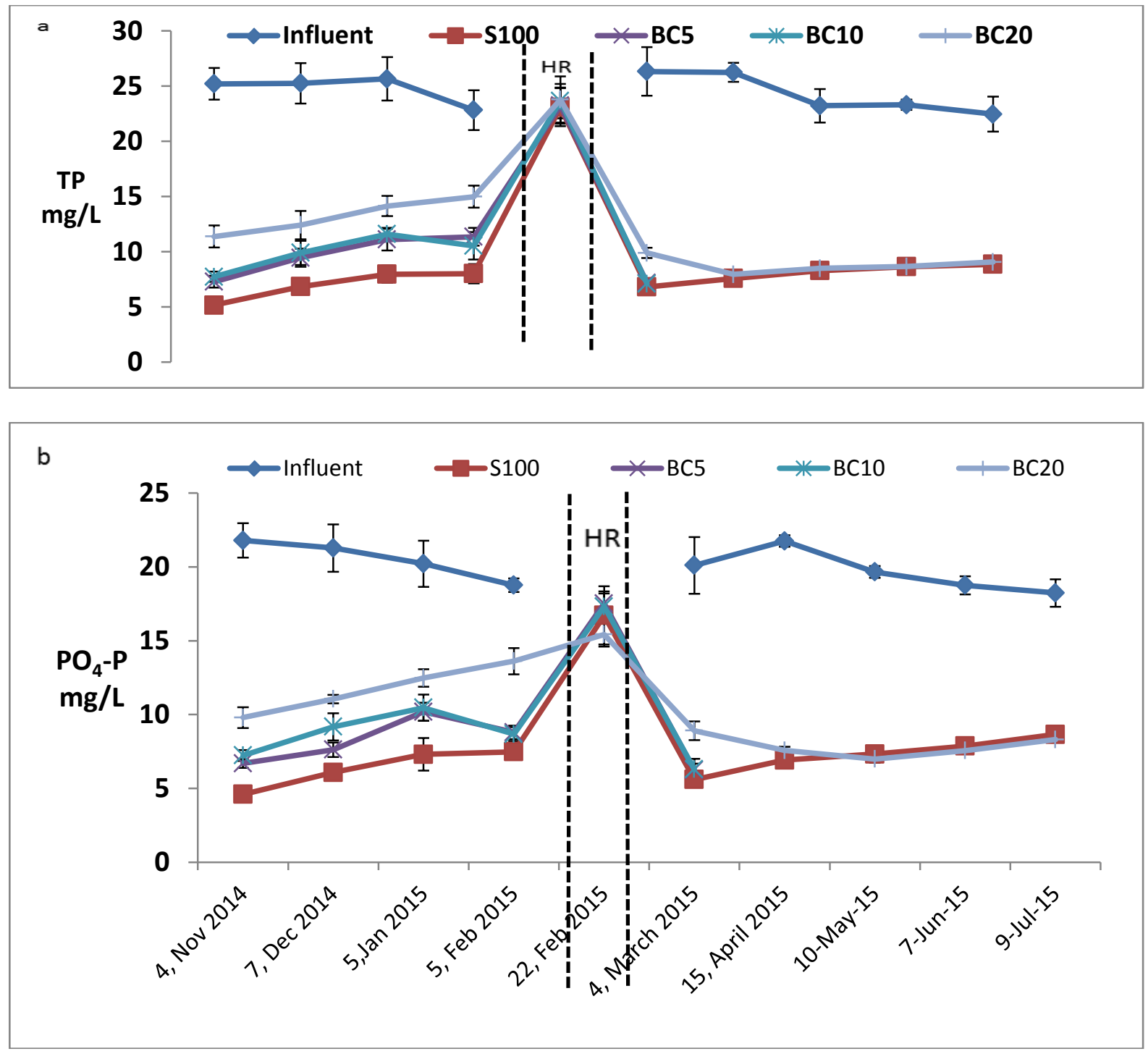

Figure 5: Experiment 4- Total $P$ (a) and Ortho-phosphate $P$ (b) influent and outflow concentrations during septage loading regime $\left(\mathbf{m g}^{-\mathbf{L}^{-1}}\right)$.NB Samples on 22 Feb. 2015 followed a 200mm rainfall event HR. Source: de Rozari et al. 2016 


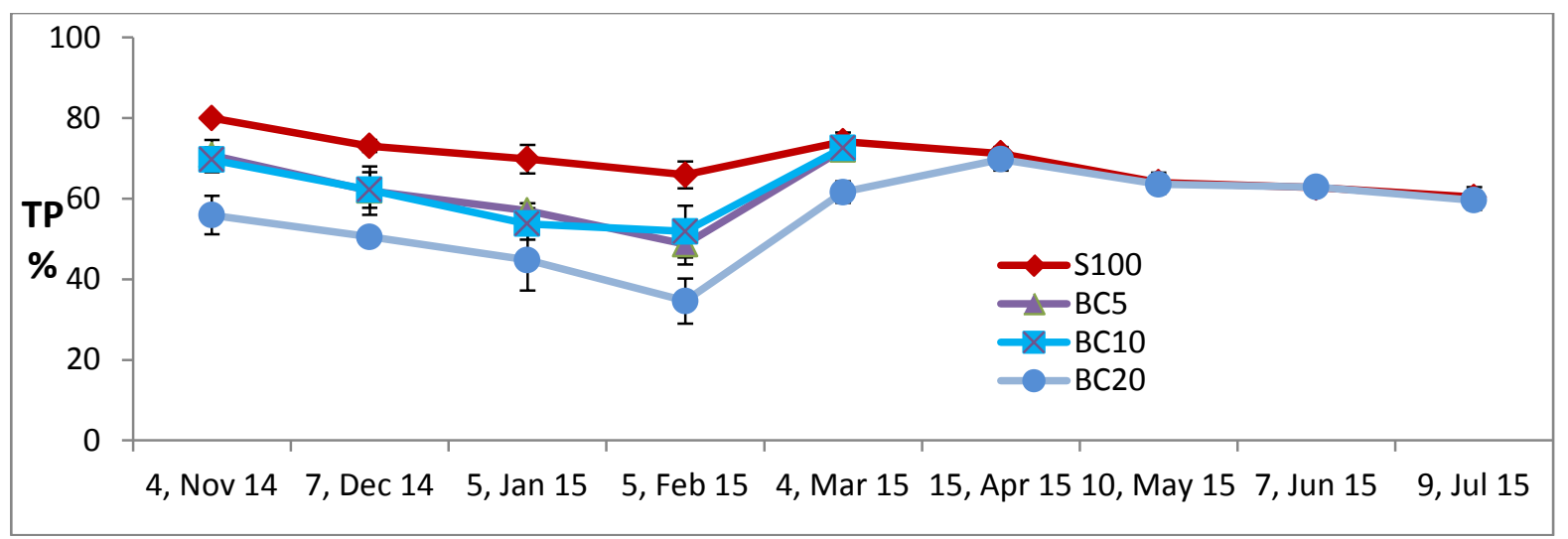

Figure 6: Experiment 4- \% Removal Total $P$ during septage loading regime (mg- $\left.\mathrm{L}^{-1}\right)$

NB 200mm rainfall event between February and March samples. Source: de Rozari et al. 2016

\section{Plant biomass and nutrient accumulation:}

Of the herbaceous plants Pennisetum and Carex had the highest nutrient accumulation. Cropping shoots enhanced shoot growth. In Experiment 1 plant growth was highest in the loam media (Gautum and Greenway, 2014; Lucas and Greenway, 2008). In Experiment 2 plant growth was similar in all sandy loam media with amendments (Greenway \& Lucas, 2010). In Experiment 4 growth of Melaleuca and Cymbopogon citratus (lemongrass) was highest in the sand media without biochar (de Rozari et al., 2016).Of the shrubs Callistemon and Melaleuca had the highest biomass. Plant uptake in Expt 1 after 4 years maturity ranged from $7 \mathrm{gP}$ in the sand /gravel media to 11g/m2/y in the loam. In Expt 2 and 3 after 2-3 years maturity plant uptake ranged from $11 \mathrm{gP}$ to $17 \mathrm{gP} / \mathrm{m} 2 / \mathrm{y}$ (Greenway and Lucas, 2010). Higher removal rates were attributed to luxury uptake (Greenway, 2007) and regular shoot harvesting in Pennisetum, Vetiver and Carex which invigorated regrowth. In Expt 4 after 2 years plant uptake ranged from $4.1 \mathrm{gP} / \mathrm{m} 2$ in sand $+25 \%$ biochar to $5 \mathrm{gP} / \mathrm{m} 2$ in sand only, with Melaleuca yielding the highest biomass 4.6gP(de Rozari et al., 2016). Over 2 years Pennisetum, Vetiver and Melaleuca yielded the highest carbon content 800-950 gC/m2/y. However after 4 years the total carbon content of the woody species was almost $4000 \mathrm{~g} / \mathrm{m} 2$.

\section{CONCLUSION}

In experimental trials conducted over 2-4 years sand amended with Red Mud, Krasnozem soils and Water Treatment Residuals were highly effective in phosphorus removal, with up to 99\% retention in the WTRK, WTR30, WTRMC treatments. The addition of Biochar to sand media did not improve $\mathrm{P}$ retention over 2 years however following rainfall leaching $\mathrm{P}$ removal increased. Sandy loam media was more effective than gravel/sand. Mature plant assemblages accounted for annual removal and incorporation into plant biomass of up to $17 \mathrm{gP} \mathrm{m}^{-2}$ and $1000 \mathrm{gC} \mathrm{m}^{-2}$. The woody species Callistemon and Melaleuca had the highest carbon sequestration.

\section{REFERENCES}

Abou-Elela, S. I., Golinielli, G., Abou-Taleb, E. M. \& Hellal, M. S. 2013. Municipal Wastewater Treatment In Horizontal And Vertical Flows Constructed Wetlands. Ecological Engineering, 61, 460468.

Arias, C., Del Bubba, M. \& Brix, H. 2001. Phosphorus Removal By Sands For Use As Media In Subsurface Flow Constructed Reed Beds. Water Research, 35, 1159-1168. 
Arias, C. \& Brix, H. 2001. Phosphorus Removal In Constructed Wetlands; Can Suitable Alternative Media Be Identified. Water Sci.Technol. , 51: 267-274

Ayaz, S. Ç., Aktaş, Ö., Findik, N. \& Akça, L. 2012. Phosphorus Removal And Effect Of Adsorbent Type In A Constructed Wetland System. Desalination And Water Treatment, 37, 152-159.

De Rozari, P., Greenway, M. \& El Hanandeh, A. 2015. An Investigation Into The Effectiveness Of Sand Media Amended With Biochar To Remove Bod5, Suspended Solids And Coliforms Using Wetland Mesocosms. Water Sci. Technol. 71;156-1544

De Rozari, P., Greenway, M. \& El Hanandeh, A. 2016. Phosphorus Removal From Secondary Sewage And Septage Using Sand Media Amended With Biochar In Constructed Wetland Mesocosms. Water Research (Submitted).

Gautam, D.N \& M. Greenway (2014) Nutrient Accumulation In Five Plant Species Grown In Bioretention Systems Dosed With Wastewater, Australasian Journal Of Environmental Management, 21:4, 453-462.

Greenway, M., 2004. Constructed wetlands for water pollution control - processes, parameters and performance. Dev. Chem. Eng. Miner. Process., 12(5/6): 491-504

Greenway, M. (2005). The role of constructed wetlands in effluent treatment and water reuse in subtropical and arid Australia. Ecological Engineering 25:501-509

Greenway, M 2007, 'The Role Of Macrophytes In Nutrient Removal Using Constructed Wetlands', In Sn Singh \& Rd Tripati (Eds.), Environmental Bioremediation Technologies, Springer, Verlag, Berlin Heidelberg, Pp. 331-351.

Greenway, M \& W. C. Lucas. (2009). A Comparative Study Of Nutrient Removal In Intermittently Loaded Vegetated And Non-Vegetated Vertical Flow Bioretention Mesocosms. 6th International Water Sensitive Urban Design \& Hydropolis No. 3 May 5-9, 2009 Perth, WA, Australia

Greenway, M \& B. Lucas. (2010). Improved Media and Plant Species For Long Term Sustainability Of Nutrient Retention In Bioretention Systems. Presented At Stormwater 2010 Stormwater Industry Association National Conference 9-11 November 2010 Sydney, Australia

Henderson, C., M. Greenway, \& I. Phillips (2007). "Removal Of Dissolved Nitrogen, Phosphorus And Carbon From Stormwater Biofiltration Mesocosms”. Water Sci. Technol. 55(4):183-191

Henderson C; Greenway M \& Phillips I (2007b). Sorption Behaviour Of Nutrients In Loamy-Sand Bioretention Media Subject To Different Conditions (Vegetation Enrichment And Incubation Time). In Proceedings Rainwater And Urban Design 2007. 5th International Water Sensitive Urban Design Conference. 21-23 August 2007. Sydney Australia.

Henderson, C. (2008). “Chemical And Biological Mechanisms Of Nutrient Removal From Stormwater In Bioretention Systems”. Phd Thesis. Griffith University, Australia

Kadlec, R. H. \& Wallace, S. 2008. Treatment Wetlands, Crc Press. 
Lucas, W. C. (2013). Interactions of Hydraulics And Biogeochemistry Involved In Nutrient Retention By Bioretention Mesocosms. PhD Dissertation. Griffith University, Australia

Lucas, W \& Greenway, M (2007). Phosphorus Retention Performance In Vegetated And NonVegetated Bio-Retention Mesocosms Using Recycled Effluent. In: Proceedings Rainwater And

Lucas, W. C. \& Greenway, M (2008). "Nutrient Retention In Vegetated And Nonvegetated Bioretention Mesocosms”. J. Irrigation And Drainage Eng. 133(5):613-623

Lucas, W. C. \& M. Greenway (2009). “A Study Of Nutrient Retention Dynamics In Vegetated And Non-Vegetated Bioretention Mesocosms” Pp- 140-158 In Low Impact Development: New And Continuing Applications. 2009. Michael Clar (Editor) Asce, Reston Va.

Lucas, W. C. \& M Greenway, (2011a). "Phosphorus Retention Response To Accelerated Loads By Bioretention Mesocosms With Media Formulated For Phosphorus Sorption” J. Irrigation And Drainage Eng. 137(3):144-153

Martín, M., Gargallo, S., Hernández-Crespo, C. \& Oliver, N. 2013. Phosphorus And Nitrogen Removal From Tertiary Treated Urban Wastewaters By A Vertical Flow Constructed Wetland. Ecological Engineering, 61, 34-42.

Sani, A., Scholz, M. \& Bouillon, L. 2013. Seasonal Assessment Of Experimental Vertical-Flow Constructed Wetlands Treating Domestic Wastewater. Bioresource Technology, 147, 585-596.

Vohla, C., Kõiv, M., Bavor, H. J., Chazarenc, F. \& Mander, Ü. 2011. Filter Materials For Phosphorus Removal From Wastewater In Treatment Wetlands-A Review. Ecological Engineering, 37, 70-89.

Vymazal, J (2007). Removal of Nutrients In Various Types Of Constructed Wetlands. Science Of The Total Environment. 380 (1-3):48-65

Westholm, L. J. 2006. Substrates for Phosphorus Removal-Potential Benefits For On-Site Wastewater Treatment? Water Research, 40, 23-36. 